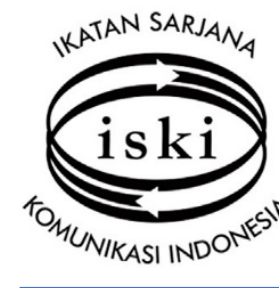

\title{
Aktivitas Promosi Media Sosial Instagram dan Sikap Konsumen Muda Produk Batik Lokal
}

\author{
https://doi.org/10.25008/wartaiski.v3i02.62
}

\author{
S.M. Niken Restaty ${ }^{1}$, AG Eka Wenats Wuryanta ${ }^{2 *}$ \\ ${ }^{1}$ Program Studi Ilmu Komunikasi, Universitas Mercubuana, \\ Jl. Meruya Selatan, Jakarta 11650 - Indonesia \\ 2 Program Studi Ilmu Komunikasi, Universitas Paramadina, \\ Jl. Gatot Subroto Kav 97, Jakarta 12790 - Indonesia \\ *e-mail korespondensi: eka.wenats@paramadina.ac.id
}

Submitted: 19/05/2020, Revised: 04/12/2020, Accepted: 17/12/2020

Accredited by Kemristekdikti No. 30/E/KPT/2019

\begin{abstract}
Batik business is a profitable business sector for micro, small, and medium entrepreneurs or MSMEs. Of course, they need promotion through marketing communication to get consumers interested in their products. Effective promotion through social media is one of the models of marketing communication mix directly related to the level of consumers' exposure where they decide to buy local batik products. This research aims to analyze how effective is the promotion of local batik products through the instagram, including factors related to the effective promotion of batik products and the characteristics of local batik consumers. This research uses a quantitative approach to measure how effective is the promotion with the characteristics of young consumers of local batik products. The quantitative approach used in this study is survey research. The results of this study show that Instagram account used for the promotion of local batik products has not been effective to increase the commercial attitude of local batik makers. This research also found that the promotion of local batik and the formation of marketing communication using other social media such as Youtube can motivate youths or others to produce local batik.
\end{abstract}

Keywords: new media; instagram; marketing communication; batik; promotion.

\begin{abstract}
Abstrak
Usaha batik merupakan sektor yang menguntungkan bagi para pemilik usaha, terutama usaha mikro, kecil, dan menengah atau UMKM. Promosi suatu produk batik oleh seorang pelaku usaha tentunya membutuhkan promosi melalui komunikasi pemasaran agar konsumen tertarik dengan produk yang ditawarkan. Efektivitas promosi melalui media sosial merupakan salah satu bentuk bauran komunikasi pemasaran yang berhubungan langsung dengan tingkat keterpaparan konsumen di mana konsumen memutuskan untuk membeli produk batik lokal. Penelitian ini ingin mengetahui dan menganalisis efektivitas promosi produk batik lokal melalui Instagram berikut faktor-faktor yang berhubungan dengan efektivitas promosi produk batik dan karakteristik konsumen muda produk batik lokal. Penelitian ini menggunakan pendekatan kuantitatif karena penelitian ini bertujuan untuk mengukur efektivitas dan manajemen hubungan serta pengaruh efektivitas promosi dengan karakteristik konsumen dalam hal ini konsumen muda produk batik lokal. Pendekatan kuantitatif yang digunakan adalah penelitian survei terhadap responden. Temuan menunjukkan bahwa akun Instagram Promosi Batik Lokal belum efektif meningkatkan sikap pembatik lokal. Penelitian ini juga menemukan bahwa promosi dan pembentukan komunikasi pemasaran namun dengan media yang berbeda seperti Youtube dapat memotivasi anak muda atau khalayak lainnya, selain itu juga harus membangun komunitas yang dibutuhkan untuk terus membangun kesadaran dan pemahaman serta promosi yang tepat untuk batik lokal.

Kata Kunci: media baru; instagram; komunikasi pemasaran; promosi; batik
\end{abstract}




\section{PENDAHULUAN}

Indonesia memiliki kekayaan warisan budaya yang beragam salah satunya adalah kain khas Indonesia seperti batik, songket, dan tenun. Semenjak batik diresmikan UNESCO sebagai Warisan Kemanusiaan untuk Budaya Lisan dan Non-bendawi pada 2 Oktober 2009, trend kain batik semakin meningkat. Masyarakat mulai berlomba-lomba menggunakan pakaian dengan sentuhan batik dalam aktivitas sehari-hari. Hal ini membuat usaha batik menjadi sektor yang menguntungkan bagi para pemilik usaha terutama para pelaku usaha mikro kecil dan menengah (UMKM) karena jika lebih dikembangkan lagi bisa memiliki nilai lebih karena membawa warisan budaya Indonesia.

Data Kementerian Perindustrian menunjukkan jumlah unit usaha selama lima tahun sejak 2011 hingga 2015 tumbuh 14,7\% dari 41.623-unit menjadi 47.755 unit. Tenaga kerja pun sama, selama 20112015 tumbuh $14,7 \%$ dari 173.829 orang menjadi 199.444 orang. Nilai pembelian bahan baku pun meningkat 12,8\% dari tahun 2011 senilai Rp 4,137 triliun menjadi Rp 4,746 triliun pada tahun 2015 . Nilai tambah batik tumbuh 14,7\% dari tahun 2011 senilai Rp 1,909 triliun menjadi Rp 2,191 triliun.

Peminat batik dari mancanegara yang meningkat pun tercermin dari nilai ekspor batik yang naik 14,7\% dari tahun 2011 senilai $\mathrm{Rp} \mathrm{43,96} \mathrm{triliun} \mathrm{menjadi} \mathrm{Rp} \mathrm{50,44} \mathrm{triliun} \mathrm{pada} \mathrm{2015.} \mathrm{Dalam}$ perkembangan selanjutnya data terakhir perkembangan ekspor batik adalah sebagai berikut:

Badan Pusat Statistik (BPS) mencatat volume ekspor batik Indonesia periode Januari-Juli 2019 sebesar 18,5 ribu ton. Namun secara tahunan, volume ekspor batik Indonesia tercatat menurun, $72 \%$ dari 38,1 ribu ton menjadi 35,1 ribu ton.

Tingginya animo masyarakat terhadap produk kain batik ini membuat banyak pelaku usaha berlomba-lomba membuat inovasi trend berbusana batik tradisional namun tetap terlihat modern sehingga penggemarnya pun berasal dari berbagai kalangan dan usia. Promosi sebuah produk batik yang dilakukan pemilik usaha tentu memerlukan sebuah promosi melalui komunikasi pemasaran agar konsumen tertarik dengan produk yang ditawarkan.

Komunikasi pemasaran dilakukan melalui bauran pemasaran yang menurut Kotler (2003) terdiri atas product, price, promotion, dan place atau sering dikenal dengan 4P's. Penjualan yang biasa dilakukan dalam memasarkan produk adalah pemasaran konvensional yang menggunakan cara umum seperti membuat toko sehingga penjualan dilakukan secara tatap muka. Namun pemasaran konvensional dirasa sudah tidak menarik karena jangkauannya yang terbatas dan masih mengeluarkan biaya cukup besar. Dewasa ini, kegiatan penjualan barang dan jasa (direct selling) tidak hanya dilakukan melalui kegiatan kovensional namun juga dapat dilakukan melalui internet atau yang biasa disebut dengan E-Commerce.

Tujuan komunikasi yang dapat dicapai perusahaan melalui penggunaan internet antara lain terkait dengan penyebaran informasi, menciptakan kesadaran, tujuan riset, menciptakan persepsi, percobaan produk, meningkatkan pelayanan, dan meningkatkan distribusi. Hal tersebut sejalan dengan UndangUndang Republik Indonesia Nomor 11 Tahun 2008 tentang Informasi dan Transaksi Elektronik yang menyebutkan, pemanfaatan teknologi informasi dan transaksi elektronik salah satunya dilaksanakan dengan tujuan untuk mengembangkan perdagangan dan perekonomian nasional dalam rangka meningkatkan kesejahteraan masyarakat.

Penjualan produk kain batik melalui bisnis online ini membuka jalan bagi kain batik untuk dikembangkan sampai ke seluruh Indonesia bahkan ke mancanegara. Penjualan produk kain batik melalui internet dapat dilakukan dalam beberapa cara yaitu transaksi langsung di website, facebook, twitter, dan instagram dengan sistem pembayaran dan pelayanan yang beragam.

Menjamurnya bisnis jual beli produk kain batik melalui instagram dikarenakan banyaknya kemudahan yang ditawarkan bisnis melaui media sosial ini seperti jangkauan konsumen yang sampai ke mancanegara, lebih efisien, dan lebih mudah dalam penyampaian informasinya. Instagram juga banyak diminati oleh masyarakat karena dapat di akses di smartphone yang dimiliki oleh masyarakat dengan fitur-fitur pendukung di dalamnya seperti mengunggah foto atau video yang kiranya mendukung para pelaku usaha untuk menjadikan Instagram sebagai media promosi online mereka. Dengan demikian kedua belah pihak diuntungkan karena konsumen dapat memilih dan mendapatkan produk dengan mudah dan konsumen dapat menjual barang atau jasa dengan praktis dan terjangkau luas.

Pengguna internet di Indonesia tercatat mengalami peningkatan dari tahun ke tahun. Berdasarkan hasil studi Polling Indonesia bekerja sama dengan Asosiasi Penyelenggara Jasa Internet Indonesia (APJII), tahun 2018, jumlah pengguna internet di Indonesia tumbuh 10,12 persen. Dari total populasi sebanyak 264 juta jiwa penduduk Indonesia, sebanyak 171,17 juta jiwa atau sekitar 64,8 persen sudah 
terhubung ke internet. Angka ini meningkat dari tahun 2017 saat angka penetrasi internet di Indonesia sebanyak 54,86 persen.

Kontribusi terbesar atas penetrasi internet di Indonesia berasal dari Pulau Jawa. Angka penetrasi di pulau ini mencapai 55 persen dari total keseluruhan. Sementara Pulau Sumatera berada di posisi kedua dengan menyumbang penetrasi sebesar 21 persen. Di Pulau Jawa, Provinsi Jawa Barat menjadi wilayah dengan angka pengguna internet terbesar yang mencapai 16 persen. Sementara di Pulau Sumatera, Provinsi Sumatera Utara menjadi wilayah dengan jumlah pengguna internet terbesar yang mencapai angka 6,3 persen.

Penduduk di wilayah rural masih menghadapi kendala berhubungan dengan dunia maya. Ada 171,17 juta pengguna internet Indonesia tahun 2018. Bila berbicara dari segi umur, maka pengguna internet tersebut dikuasi oleh milenial. Secara ringkas ditampilkan dalam Gambar 1:

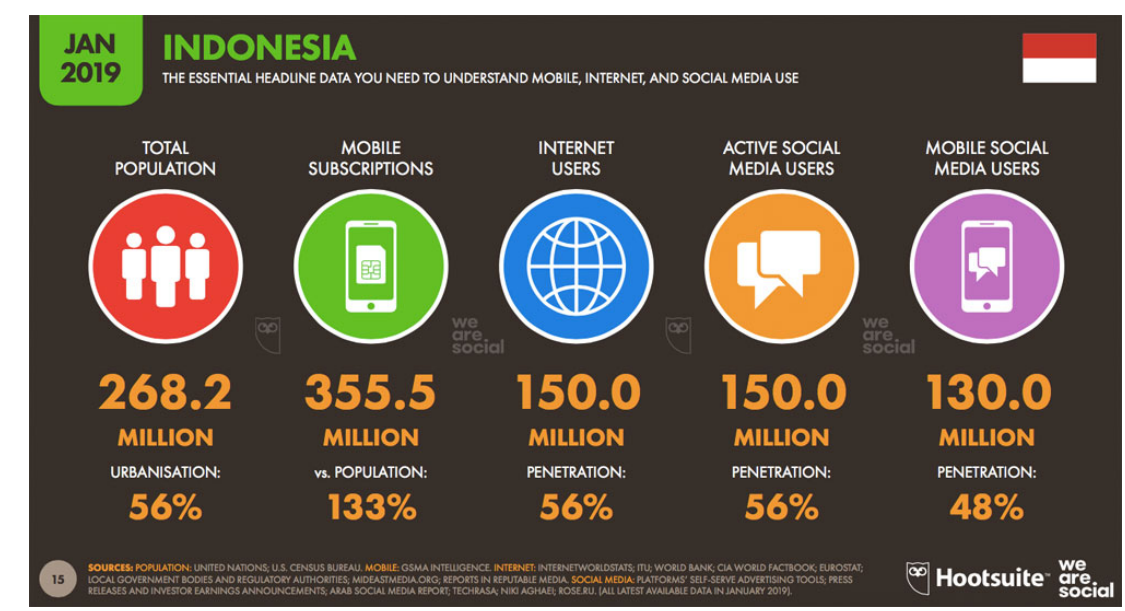

Gambar 1. Infografis Populasi dan Pengguna Internet dan Media Sosial Indonesia Sumber: Hotsuite, 2019

Dengan data tersebut terlihat penetrasi internet mengalami kenaikan yang signifikan. Dalam laporan Digital Around the World 2019, terungkap dari 268,2 juta penduduk di Indonesia, 150 juta di antaranya menggunakan media sosial. Dengan demikian, angka penetrasinya sekitar 56 persen. Hasil riset yang diterbitkan 31 Januari 2019 itu memiliki durasi penelitian dari Januari 2018 hingga Januari 2019. Terjadi peningkatan 20 juta pengguna media sosial dibanding tahun sebelumnya. Generasi milenial, generasi Y serta generasi Z, mendominasi penggunaan media sosial. Pengguna media sosial paling banyak berada pada rentang usia 18-34 tahun, dengan dominasi pria berusia 18-24 tahun, jumlahnya mencapai 18 persen, lebih unggul dari wanita dengan persentase 15 persen.

Lalu bagaimana dengan konteks media sosial instagram? Dapat dilihat pada Gambar 2:

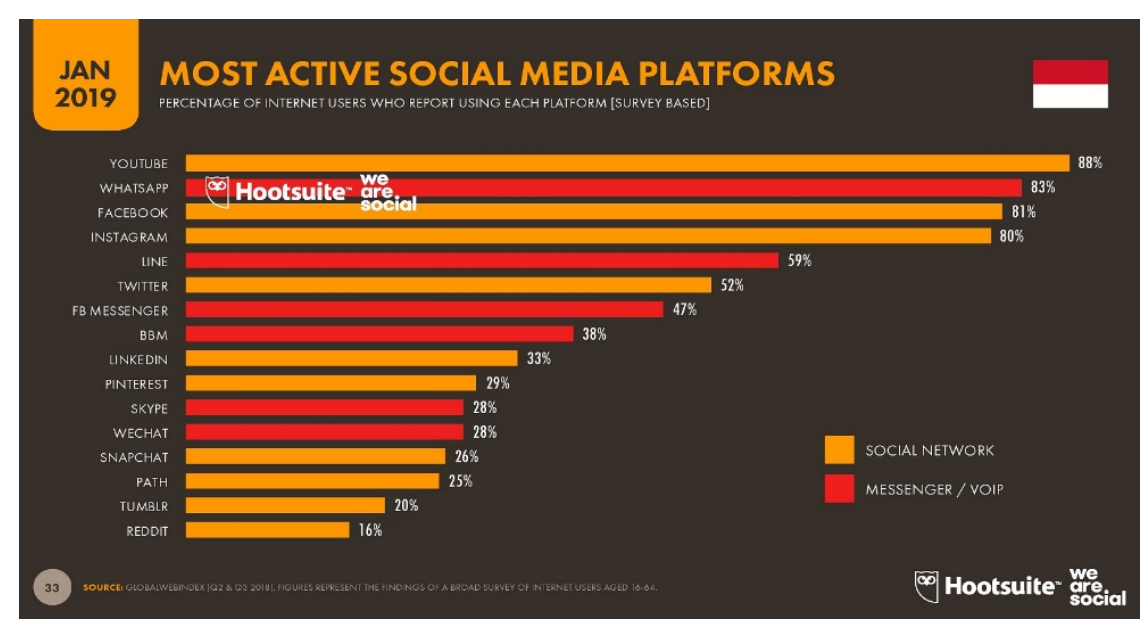

Gambar 2. Platform Media Sosial Paling Aktif di Indonesia Sumber: Hotsuite, 2019 
Pengguna intagram menempati posisi nomor empat pada platform media sosial di Indonesia. Hampir $80 \%$ populasi pengguna media sosial menggunakan intagram yang pada dasarnya mereka adalah golongan muda. Dari data tersebut dapat ditarik pernyataan pengguna internet di Indonesia semakin hari semakin bertambah jumlahnya terutama media sosial intagram. Hal tersebut kembali lagi menjadi peluang besar bagi pelaku usaha produk dari kain batik untuk bisa memasarkan produknya lebih luas. Dewasa ini beberapa pelaku usaha telah menggunakan media sosial intagram dalam mempromosikan ataupun memasarkan produknya kepada konsumen karena dinilai mudah dan tanpa mengeluarkan biaya pemasaran produknya (Wuryanta \& Utami, 2020).

Beberapa pengusaha dan UMKM batik merupakan beberapa pengguna dan memanfaatkan media sosial intagram sebagai media untuk melakukan promosi. Aktivitas promosi yang dilakukan melalui media sosial intagram berisi pesan berupa foto terkait informasi-informasi produk, iklan, proses pemesanan produk, hingga menampung aspirasi dan pertanyaan-pertanyaan yang diajukan oleh konsumen melalui fitur comment yang disediakan.

Kelebihan lain dari intagram adalah konsumen dapat melihat dengan jelas produk batik yang ditawarkan lalu dapat berkomunikasi melalui comment dan mendapatkan informasi lainnya melalui bio di profil intagram. Beberapa pengguna promosi batik gencar memberikan informasi produk, informasi tentang promo, serta testimoni yang diberikan oleh para konsumennya. Efektivitas promosi melalui media sosial merupakan salah satu bentuk bauran komunikasi pemasaran berhubungan langsung dengan tingkat eksposure konsumen hingga konsumen mengambil keputusan untuk membeli produk Batik Lokal.

Pada penelitian terdahulu, hal utama yang perlu digarisbawahi adalah komunikasi manusia semakin berkembang dengan adanya berbagai media sebagai kemajuan teknologi, sehingga manusia mudah memperoleh informasi dan melakukan kegiatan komunikasinya. Salah satu media baru dalam komunikasi yaitu internet yang berfungsi untuk menyebarkan informasi secara cepat. Selain sebagai sarana mencari informasi, internet juga mempunyai potensi besar sebagai media pemasaran. Pemasaran dengan memanfaatkan internet disebut sebagai internet marketing atau electronic marketing (Balakrishnan, Dahnil, \& Yi, 2014; Berthon, Pitt, Plangger, \& Shapiro, 2012; Jin, Muqaddam, \& Ryu, 2019).

Menurut jurnal internasional The Impact of Electronic Word of Mouth on Consumers' Purchasing Decisions (Al Mana, 2013), komentar dan reviews menjadi faktor terbesar dari para konsumen online di Arab Saudi dalam menentukan pembelian. Sebesar 80\% konsumen dari seluruh subjek penelitan lebih suka membaca review secara online melalui media sosial terlebih dahulu sebelum melakukan pembelian dalam sebuah situs online ataupun media sosial.

Persaingan bisnis saat ini membuat setiap perusahaan untuk memperhatikan kualitas produk yang ditawarkan, keinginan dan minat konsumen, kemasan produk dan promosi yang diberikan. Promosi yang dilakukan pelaku usaha saat ini sebenarnya telah beralih dari media cetak ke internet, yaitu media sosial (Al Mana, 2013; De Veirman, 2017; Goshal, 2019). Hal tersebut karena penggunaan internet di Indonesia mayoritas digunakan pada sektor perdagangan dan jasa. Hasil penelitian memperlihatkan, pengguna internet baik di wilayah Indonesia bagian Barat dan Timur, di daerah urban maupun rural mayoritas beraktivitas di sektor perdagangan dan jasa (Marius \& Anggoro, 2015).

Strategi pemasaran dengan promosi melalui internet khususnya dengan sosial media dapat meningkatkan penjualan secara luas dan tidak memerlukan biaya pemasaran yang mahal. Konsumen juga lebih mudah untuk mencari informasi mengenai produk yang ingin mereka beli karena tidak perlu tatap muka secara langsung (Berg, 2013; Werdani, 2018; Widiastuti, 2019)

Morrisan (2010: 320) mengatakan, jaringan global dan sebuah situs dapat menjadi media promosi yang sangat efektif serta alat bantu pemasaran yang tangguh. Intagram sebagai salah satu platform media sosial yang paling banyak diunduh oleh masyarakat, memungkinkan penggunanya untuk mempublikasikan berbagai foto dan ragam informasinya. Realitasnya, intagram justru dimanfaatkan sebagai salah satu media promosi dan pemasaran produk secara online (Aprilya, 2017:138).

Setelah menyimak beberapa konteks dalam latar ekonomi, sosial dan perkembangan media baru, penelitian ini bertujuan menjawab seberapa jauh efektivitas promosi produk modifikasi kain batik melalui intagram berikut faktor-faktor yang berhubungan dengan karakteristik konsumen muda batik. Dengan demikian secara sederhana, penelitian ini bertujuan untuk mengetahui dan menganalisis efektivitas promosi produk batik lokal melalui intagram berikut faktor-faktor yang berhubungan dengan efektivitas promosi produk batik dan karakteristik konsumen muda produk batik lokal. 


\section{KERANGKA TEORI}

Promosi penjualan terdiri dari kumpulan alat-alat insentif yang beragam, sebagian besar berjangka pendek, dirancang untuk mendorong pembelian suatu produk/jasa tertentu secara lebih cepat atau lebih besar oleh konsumen atau pedagang (Kotler dan Keller, 2007:266). Dari definisi tersebut dapat dikatakan, promosi merupakan cara yang dilakukan perusahaan dalam memperkenalkan dan menawarkan produk mereka kepada konsumen (Morissan, 2015). Kotler dan Keller (2009:432) mengemukakan, "Promotion mix (marketing communications mix) is the specific blend of promotion tools that the company uses to persuasively communicate customer value and build customer relationships", artinya bauran promosi (komunikasi pemasaran) adalah campuran spesifik dari alat-alat promosi yang digunakan perusahaan untuk secara persuasif mengomunikasikan nilai pelanggan dan membangun hubungan pelanggan.

Setiap kegiatan pemasaran, baik barang atau jasa pasti dalam prosesnya menggunakan komunikasi pemasaran. Menurut Kusumastuti (2009) komunikasi pemasaran adalah aplikasi komunikasi yang fungsinya menjadi faktor pendorong atau pembantu kegiatan pemasaran yang dilakukan oleh suatu perusahaan. Salah satu implementasi dari komunikasi pemasaran adalah bauran promosi (promotional mix) yang memiliki lima jenis teknik antara lain periklanan (advertising), penjualan tatap muka (personal selling), promosi penjualan (sales promotion), hubungan masyarakat dan publisitas (public relation and publicity) dan pemasaran langsung (direct selling).

Batik Indonesia adalah salah satu produk yang memiliki nilai jual tinggi karena mengandung unsur-unsur keanekaragaman budaya Indonesia. Namun dalam segi pemasarannya masih menemui kesulitan seperti terbatas pada wilayah asal dari masing-masing daerah produsen batik yang membuat konsumen belum megetahui keberadaan produk tersebut. Dalam menanggulangi hal tersebut perusahaan melakukan promosi terhahap produk barang atau jasa yang mereka tawarkan.

Promosi merupakan bagian dari komunikasi yang terdiri dari pesan-pesan perusahaan yang didesain untuk menstimulasi terjadinya kesadaran (awarness), ketertarikan (interest), dan berakhir dengan tindakan pembelian (purchase) yang dilakukan oleh pelanggan terhadap produk atau jasa yang ditawarkan. Promosi yang dilakukan dalam meningkatkan penjualan batik sekarang ini mulai mengalami pergeseran yang semula menggunakan cara promosi secara konvensional kini mulai memanfaatkan fungsi jaringan internet dalam melakukan promosi. Beberapa alasan berpindahnya strategi promosi menjadi menggunakan jaringan internet antara lain internet memiliki jangkauan yang luas sehingga dapat menyebarkan informasi terkait barang yang ditawakan secara cepat, mudah digunakan dan diakses oleh siapa saja kapan saja selama terhubung dengan jaringan internet, dan tidak mengeluarkan biaya yang besar sehingga membawa keuntungan kepada pemilik usaha dalam melakukan promosi.

Media sosial merupakan media yang digunakan para pelaku usaha untuk melakukan promosi melalui internet dan dari beberapa penelitian sebelumnya media yang sering digunakan antara lain website, facebook, twitter, intagram, dan blackberry messenger. Pelaku usaha produk batik melakukan promosi melalui media sosial seperti memberikan informasi, promo produk dan melakukan perbincangan dengan konsumen secara intensif dengan tujuan memberikan layanan prima pada konsumen sampai akhirnya terjadinya transaksi bahkan transaksi berulang. Sebuah promosi dapat dilakukan dengan berbagai macam cara mulai dari cara konvensional atau cara langsung dan melalui internet.

Sebelum adanya internet, sebuah promosi dilakukan langsung melalui pembicaraan kepada orang-orang (Word of Mouth), melalui media cetak, televisi, radio dan lainnya. Namun seiring dengan perkembangan teknologi sekarang ini promosi melalui teknik konvensional mulai ditinggalkan oleh para pelaku usaha karena mulai terlihat kekurangan-kekurangan promosi melalui jalur konvensional. Sekarang ini banyak pelaku usaha produk batik yang mulai berpindah melakukan promosi melalui media social.

\section{Efektivitas Media Sosial sebagai Media Promosi}

Efektivitas berhasil bila sasaran yang telah ditetapkan berhasil sesuai dengan tujuan tertentu. Semakin hasil mendekati tujuan yang diinginkan maka semakin tinggi derajat keefektivitasannya. Efektivitas komunikasi dapat memengaruhi keberhasilan bagi efektivitas media sosial sebagai media 
promosi. Proses komunikasi pemasaran bisa dikatakan efektif apabila pemasar melancarkan kegiatan sedemikian rupa sehingga pembeli melewati tahap kognitif, afektif dan perilaku.

Kemunculan media sosial telah merubah, atau paling tidak telah menggeser paradigma komunikasi pemasaran baik bisnis maupun sosial dari model AIDA: menarik kepedulian (Attention) pelanggan, menarik minat (Interest) pelanggan, serta menumbuhkan keinginan (Desire) pelanggan, dan terakhir mendorong pelanggan untuk memutuskan (Action) pembelian barang dan jasa yang diiklankan, ke model AISAS: A (Attention) yaitu menarik perhatian target audience, I (Interest) yaitu menarik minat target audience, S (Search), mendorong target audience untuk membeli produk yang diiklankan, A (Action), mendorong target audience untuk membeli produk yang diiklankan, dan S (Share) yaitu mendorong target audience untuk berbagi pengalaman mengenai produk yang diiklankan.

Dengan demikian komunikasi pemasaran khususnya iklan telah bergeser dari hanya berjalan satu arah (one way communication), menjadi berjalan dua arah (two ways communication). Model AISAS muncul pada tahun 2004, didorong oleh penggunaan internet dan sosial media diawal 2000-an. Model ini dikembangkan oleh Dentsu (perusahaan international iklan dan public relation Jepang, yang bermarkas di Gedung Dentsudi distrik Shiodome Minato, Tokyo), dirancang dan diterbitkan sebagai representasi dari pengembangan perilaku konsumen.

Adapun secara rinci aspek-aspek AISAS adalah sebagai berikut: Perhatian (Attention) pada tahap awal, sebagian besar target audience tidak menyadari produk atau merek dan oleh sebab itu tujuan komunikator adalah membangun kesadaran, mungkin hanya sebuah pengakuan nama dengan pesan sederhana yang mengulangi nama merk, atau memberikan informasi dasar tentang produk. Dalam kategori produk yang relatif baru, fungsi asumsi ini penting dimaksimalkan.

Ketertarikan (Interest), pada tahap ini konsumen lulus dari kesadaran tentang produk, kemudian tertarik dengan produk tersebut. Pemasar perlu mengetahui apa yang konsumen rasakan tentang produk mereka. Apakah produk tersebut dibuang? Apakah mereka menyukainya? Apakah mereka menemukan hal yang cukup menarik? Minat terhadap produk dapat dibuat dengan menunjukan beberapa fitur unik dari produk, menunjukkan cara kerjanya, menyajikan iklan yang menghibur, menggunakan selebriti populer dan lain lain.

Mencari Informasi (Search). Setelah target audience menyadari tentang produk dan tertarik, fungsi iklan adalah untuk membuat mereka cenderung ke arah positif untuk mencari informasi mengenai produk yang diiklankan, dengan menciptakan keinginan dan preferensi untuk produk yang diiklankan. Keinginan dapat dibangun dengan menunjukkan bagaimana produk memenuhi kebutuhan spesifik konsumen dan dengan kreatif melakukan promosi yang berkualitas, nilai dan fitur penting lainnya.

Tindakan (Action). Iklan belum memainkan bagiannya sampai mereka telah mencapai tujuan mereka yaitu mendorong target audience untuk melakukan tindakan. Dalam kebanyakan kasus, tindakan yang diinginkan adalah mendorong konsumen untuk membeli, tetapi dalam kasus tertentu juga bisa untuk menghasilkan pertanyaan, menyebabkan kunjungan ritel, menunjukkan partisipasi dalam promosi dan lain-lain. Iklan yang membangun merek atau sikap khalayak, tidak akan langsung mendapatkan tindakan untuk pembelian, tetapi akan menciptakan preferensi dan keinginan yang pada akhirnya akan menghasilkan pembelian. Hal ini merupakan strategi jangka panjang. Di sisi lain, pembicaraan atau promosi iklan langsung melalui penawaran insentif kepada konsumen jika mereka langsung membeli produk, hal ini merupakan strategi jangka pendek.

Membagikan Informasi (Share). Setelah mereka melakukan tindakan pembelian, promosi melalui media promosi mendorong konsumen untuk membagikan informasi dan pengalaman mengenai produk yang diiklankan. Dengan demikian model AISAS ini akan berjalan dua arah (two ways communication).

\section{Karakteristik dan Perilaku Konsumen}

Perilaku dan karakteristik konsumen merupakan faktor yang memengaruhi perilaku seseorang dalam melakukan pembelian suatu produk atau jasa. Perilaku konsumen mempunyai proses yang dinamis yang mencakup perilaku konsumen individual, kelompok dan anggota masyarakat yang secara terus menerus mengalami perubahan (Sumarwan, 2011; Firmansyah, 2019). Keputusan pembeli yang diambil memengaruhi permintaan terhadap bahan-bahan baku dasar, transportasi, produksi, perbankan; juga memengaruhi kesempatan kerja para pekerja dan pemanfaatan lain.

Tidak dapat dipungkiri, perilaku konsumen telah menjadi faktor terpadu dalam pasang surutnya semua bisnis dalam ekonomi dunia yang sibuk ini. Konsumen merupakan titik pusat perhatian dalam 
suatu pemasaran. Untuk mengetahui keinginan dan kebutuhan konsumen, aspek-aspek yang memengaruhi konsumen secara individu seperti persepsi, cara memperoleh informasi, sikap, demografi, kepribadian dan gaya hidup konsumen perlu dianalisis. Perilaku konsumen mempelajari tentang bagaimana individu, kelompok dan organisasi serta proses yang dilakukan untuk memilih, mengamankan, menggunakan dan menghentikan produk, jasa, pengalaman atau ide untuk memuaskan kebutuhannya dan dampaknya terhadap karakteristik konsumen dan masyarakat.

Karakteristik konsumen berdasarkan demografi adalah: (1) Usia. Individu dibedakan menurut usia anak-anak, remaja, dewasa, dan orang tua. Pada usia dewasa, dikategorikan menjadi dewasa awal, dewasa pertengahan dan dewasa tua. Usia yang berbeda akan mengkonsumsi produk dan jasa yang berbeda, perbedaan terjadi pada selera dan kesukaan terhadap merek: (2) Jenis Kelamin. Individu dibedakan berdasarkan jenis kelamin perempuan dan jenis kelamin laki-laki. Beberapa produk ditunjukkan hanya kepada perempuan atau hanya kepada laki-laki; (3) Pendidikan. Individu dapat dikelompokkan menurut tingkat pendidikan yang dicapai. Pendidikan individu dapat memengaruhi proses keputusan dan pola konsumsi seseorang.

Konsumen yang memiliki pendidikan lebih baik akan sangat responsif terhadap informasi, pendidikan juga memengaruhi konsumen dalam pilihan produk maupun merek. Pendidikan yang berbeda akan menyebabkan selera konsumen juga berbeda; (4) Pekerjaan. Individu dapat dikelompokkan menurut pekerjaan yang sedang dijalani saat ini, seperti pegawai negeri sipil, wiraswasta, pelajar atau mahasiswa, ibu rumah tangga; (5) Pendapatan. Individu yang berpendidikan tinggi diasumsikan juga memiliki pendapatan yang tinggi. Individu pada umumnya menerima pendapatan dalam bentuk uang. Pendapatan sangat penting bagi konsumen, dari pendapatan tersebut konsumen bisa membiayai kegiatan konsumsinya. Jumlah pendapatan akan menggambarkan besarnya daya beli dari seseorang konsumen

\section{METODE PENELITIAN}

Penelitian ini memakai pendekatan kuantitatif karena penelitian ini bertujuan untuk melakukan pengukuran efektivitas dan pengelolaan hubungan dan pengaruh efektivitas promosi dengan karakteristik konsumen dalam hal ini konsumen muda produk batik lokal. Pendekatan kuantitatif yang digunakan adalah penelitian survai kepada responden. Menurut Singarimbun dan Effendi (2008), penelitian survai adalah penelitian yang mengambil sampel dari populasi dan menggunakan kuisioner sebagai alat pengumpul data primer.

Jumlah responden berjumlah 100 orang didasarkan pada jumlah responden yang merespon kuesioner yang diberikan sebelumnya. Populasi responden yang dipilih adalah pengguna aktif media sosial intagram dan me-follow beberapa akun intagram UMKM batik lokal, baik di Jakarta dan beberapa belahan Jawa Barat, Jawa Timur dan Jawa Tengah, sampai pada waktu penyebaran 20 kuesioner, yaitu lebih dari 15335 followers.

Jumlah sampel yang diambil menggunakan rumus Slovin. Metode pengambilan sampel dalam penelitian ini adalah non-probability sampling dengan prosedur accidental sampling, yaitu teknik dengan peneliti memilih sampel secara spontan atau siapa saja yang dianggap dapat mewakili populasi.

Pengolahan data dilakukan setelah hasil kuesioner dari responden yang membalas kuesioner online terkumpul. Seluruh data di entry ke dalam komputer dengan menggunakan program Microsoft Excell 2010 dan SPSS (Statistical Program for Social Sciences) 20.0 for windows. Kuesioner penelitian diuji reliabilitas dan mendapatkan angka cronbach alpha sebesar 0.83 yang berarti bahwa kuesioner penelitian reliabel digunakan untuk uji selanjutnya.

Data kemudian dianalisis menggunakan uji korelasi Pearson Correlation. Pengolahan data jumlah responden disesuaikan dengan efektivitas promosi AISAS yang hasilnya dapat dilihat adanya perubahan dari tahapan demi tahapan dimana setiap perpindahannya mengalami pengurangan jumlah responden. Uji korelasi Pearson digunakan untuk mengetahui hubungan antara karakteristik konsumen (umur, pendidikan, dan pendapatan) aktivitas promosi dan faktor psikologis dengan efektivitas promosi melalui media sosial intagram. Variabel-variabel tersebut menggunakan skala interval.

\section{HASIL PENELITIAN}

Dalam kuesioner yang dibagikan, terdapat beberapa jenis pertanyaan yang berhubungan dengan identitas responden dan pernyataan yang berkaitan dengan penelitian. Penyebaran kuesioner dilakukan dengan aplikasi survei online, Google Form yang dikirim peneliti melalui direct message instagram. 
Berdasarkan data yang masuk ke dalam penelitian ini, jenis kelamin responden terdiri dari lakilaki dan perempuan. Jumlah responden laki-laki adalah 64 orang dengan persentase $64 \%$, sementara jumlah responden perempuan adalah 36 orang dengan persentase $36 \%$. Hasil ini sudah menunjukkan bahwa responden terbanyak untuk penelitian ini adalah laki-laki.

Bagian penelitian ini juga menunjukkan, jumlah responden dengan usia kurang dari 20 tahun mencapai enam orang dengan persentase $6 \%$, usia 20 sampai 25 tahun ada 41 orang dengan persentase $41 \%$, sementara 37 responden berusia $26-30$ tahun dengan persentase $37 \%$ dan usia lebih dari 30 tahun sebanyak 16 orang dengan persentase $16 \%$.

Berdasarkan perhitungan data yang didapatkan dalam penelitian ini maka didapat hasil perhitungan korelasi antara efektivitas promosi intagram batik lokal dengan sikap khalayak. Data menunjukkan nilai korelasi antara kedua variabel tersebut sebesar 0,637. Angka tersebut menunjukkan hasil korelasi yang positif, di mana setiap satu kenaikan pada efektivitas promosi intagram batik lokal akan diikuti dengan kenaikan variabel sikpa khalayak. Berdasarkan tabel interpretasi koefisian korelasi di atas, dapat dikatakan, variabel aktivitas promosi intagram dalam penelitian ini memiliki hubungan yang kuat dengan sikap khalayak. Hal ini didapatkan dari hasil korelasi yaitu sebesar 0,637 yang berada pada interval 0,60-0,799 dan ini menunjukkan, nilai interval memiliki tingkat hubungan yang kuat.

Selain itu, nilai interval koefisien yang kuat juga menandakan bahwa semakin menarik aktivitas promosi intagram yang digunakan, maka akan kuat pula tingkat sikap khalayak di mata followers. Besarnya hubungan antara kedua variabel didorong oleh faktor hubungan yang ada pada masing-masing tiap dimensi.

Berdasarkan temuan koefisien korelasi pada pernyataan di atas maka dapat dilihat bahwa koefisien determinasi yang digunakan untuk mengetahui seberapa besar kontribusi dari efektivitas pemanfaatan Intagram (X) dalam meningkatkan Sikap khalayak (Y). Berikut adalah perhitungan dengan menggunakan rumus koefisien determinasi (Sugiyono, 2011: 231)

Nilai persentase di atas menunjukkan bahwa aktivitas promosi intagram batik lokal mempunyai kontribusi sebesar 40,5\% dalam meningkatkan sikap khalayak. Selebihnya sebesar 59,5\% dipengaruhi faktor-faktor lainnya diluar penelitian ini. Jika dilihat dari hasil uji regresi antara kedua variabel, nilai persentase di bawah 50\% yang artinya pengaruh akun instagram belum memberikan kontribusi yang kuat dalam meningkatkan sikap khalayak.

Di era globalisasi sekarang ini, teknologi informasi berperan sangat penting. Dengan menguasai teknologi dan informasi, kita memiliki modal yang cukup untuk menjadi pemenang dalam persaingan global. Informasi merupakan modal utama dalam mengembangkan ilmu pengetahuan dan teknologi yang menjadi senjata pokok untuk membangun negara.

Teknologi, menurut Miarso memiliki pengertian proses untuk meningkatkan nilai tambah, proses tersebut menggunakan atau menghasilkan suatu produk. Produk yang dihasilkan tidak terpisah dari produk lain yang telah ada, dan karena itu menjadi bagian intergal dari suatu sistem. Maka dapat disimpulkan era teknologi adalah masa dimana produk selalu didaur atau dicipta untuk memenuhi kebutuhan manusia.

Keharusan ini dimungkinkan karena manusia pada dasarnya adalah makhluk kreatif sebagai sunnatullah atas rasa, cipta, dan karsa yang diberikan maha pencipta kepadanya. Salah satu teknologi yang sedang mumpuni pada zaman sekarang ini salah satunya adalah media sosial.

Media Sosial, menurut Philip Kotler dan Kevin Keller adalah sarana bagi konsumen untuk berbagai informasi teks, gambar, video, dan audio dengan satu sama lain dan dengan perusahaan dan sebaliknya. Media sosial adalah sebuah media online dengan para penggunanya bisa dengan mudah berpartisipasi, berbagi dan menciptakan isi meliputi blog, jejaring sosial, wiki, forum, dan dunia virtual.

Media sosial sendiri dapat memiliki fungsi yang positif atau negatif, tergantung dari penggunaannya. Media sosial merupakan bagian dari internet yang memiliki fungsi salah satunya sebagai media yang digunakan untuk mempromosikan produk olahan makanan yang digunakan oleh pelaku usaha. Media sosial digunakan sebagai alat promosi karena memiliki respon secara langsung dengan penggunanya. Dewasa ini sudah mulai banyak bermunculan akun di media sosial yang digunakan untuk memasarkan produk olahan makanan secara lebih luas.

Saragih mengatakan bahwa media sosial hanyalah salah satu set alat baru, teknologi baru yang membuat kita lebih efisien dalam berhubungan dan membangun hubungan dengan pelanggan dan prospek-prospek kita. Sosial media sekarang telah memiliki peran penting dalam strategi pemasaran 
bagi bisnis kecil maupun besar. Kini berbagi informasi kepada pengunjung atau follower bukan satusatunya keuntungan menggunakan sosial media bagi sebuah bisnis.

Salah satu kunci sukses bagi seluruh bisnis dengan mengenal pelanggannya lebih dekat. Sosial media membuat proses pengenalan ini menjadi lebih mudah dibandingkan dengan sebelumnya. Dengan perangkat pendukung yang ada, kini Anda bisa mengetahui dengan terperinci mengenai siapa saja konsumen Anda, bahasa yang mereka gunakan, rentang usia, bahkan jenis kelamin dari sosial media. Informasi ini dapat membantu proses branding dan promosi kepada target konsumen yang tepat. Pelaku bisnis melihat bahwa pengguna internet menjadi sasaran empuk untuk bisnisnya ke depan. Pada era sekarang ini semakin lama semakin banyak yang menggunakan media sosial. Melihat pengguna yang makin banyak, media sosial bisa menjadi lahan untuk menaikkan profit dan memperlebar sayap bisnis.

Periklanan digital mulai menjadi tren di era internet. Para pemilik merek mulai menjadikan media digital sebagai media promosi dan pemasaran yang baru. Pada dasarnya media sosial telah mengubah bagaimana konsumen berinteraksi dan bagaimana perusahaan memasarkan produk. Adanya situs jejaring sosial menjadi peluang usaha yang baik untuk memasarkan atau mempromosikan produk yang akan dijual (Syafganti, 2018).

Kelebihan yang terdapat dalam pemasaran melalui sosial media diantaranya sebagai sarana berkomunikasi dengan konsumen, sebagai media berkolaborasi apabila adanya ketidakpuasan konsumen, sebagai media promosi, dan membangun merek. Dalam menciptakan persepsi dalam pemikiran konsumen mengenai suatu produk, jasa atau brand, dibutuhkan pemikiran yang matang akan media promosi apakah yang cocok dan efektif, agar persepsi dan image yang ingin disampaikan dapat melekat kuat dibandingkan produk, jasa atau brand lainnya yang sejenis.

Banyak media promosi yang dapat digunakan dari mulai yang umum hingga unik atau baru, hingga kini dimanfaatkan sebagai media promosi, yang ternyata cukup efektif dalam memperoleh calon konsumen baru. Ada beberapa bidang yang dapat menggunakan media sosial untuk memperkenalkan produk/jasa/brand mereka. Maraknya penggunaan media sosial oleh masyarakat Indonesia ini dilirik oleh pemilik bisnis atau perusahaan untuk memasarkan produk atau jasanya.

Iklan yang dulunya hanya kita lihat di media konvensional seperti televisi, radio, surat kabar atau majalah sekarang telah menyebar ke dunia media sosial. Media sosial saat ini telah dijadikan platform untuk memasarkan produk dan telah digunakan oleh brand brand terkemuka di dunia seperti Starbucks, Nike, Dell dan lain sebagainya. Pemasaran melalui media sosial ini disebut social media marketing. Berdasar Optima Web2, social media marketing adalah upaya pemasaran online dengan menciptakan visibilitas, eksistensi dan keberadaan sebuah situs web pada social media network (jaringan media sosial) seperti Facebook, Twitter, Intagram bahkan Youtube (Appel, Grewal, Hadi, \& Stephen, 2020; Felix, Rauschnabel, \& Hinsch, 2017; Jin, et. al., 2019; Tiago \& Veríssimo, 2014).

Singkatnya social media marketing adalah upaya pemasaran yang menggunakan media sosial sebagai salurannya. Salah satu media sosial yang populer digunakan dalam social media marketing adalah instagram. Intagram merupakan aplikasi photo-sharing yang sedang digandrungi belakangan ini. Intagram memiliki kekuatan di bidang visual. Kelebihan Intagram sebagai alat pemasaran adalah instagram dapat menyampaikan pesan dari suatu brand melalui foto/gambar atau video berdurasi 15 detik (IconoSquare, 2018). Intagram kini tidak lagi hadir sebagai selfie-platform atau media bersosialita dunia maya semata, akan tetapi telah menjadi alternatif baru dalam melancarkan aksi pemasaran.

Internet dan media sosial menambah ruang pemasaran yang lebih luas bagi pelaku usaha mikro untuk mengembangkan bisnisnya di daerah. Penggunaan media sosial seperti Twitter, Facebook, Skype, Line, WhatsApp, dan media sosial lainnya untuk layanan bisnis juga menguntungkan konsumen (Novendri et al., 2020). Tapi selama ini belum diketahui seberapa besar sebenarnya dampaknya bagi perekonomian di daerah, tempat pelaku bisnis mikro menjalankan usaha.

Riset kami menunjukkan penggunaan sosial media berasosiasi secara positif dalam peningkatan ekonomi di daerah. Peningkatan $10-20 \%$ dari penggunaan media sosial juga berhubungan secara positif dengan pertumbuhan ekonomi daerah sebesar $0,11 \%$.

Kami menganalisis data Survei Sosial Ekonomi Nasional (Susenas) 2015 dan Potensi Desa (Podes) 2014 yang mencakup lebih dari 70.000 desa dan 500 kabupaten dan kota di Indonesia. Kami menemukan bahwa daerah yang memiliki kualitas infrastruktur yang baik dan tingkat penetrasi Internet dan media sosial yang tinggi, berasosiasi dengan pertumbuhan ekonomi daerah yang lebih tinggi.

Potensi ini dapat terakumulasi lebih besar bila media sosial dapat dioptimalkan sebagai media untuk meningkatkan kehadiran online dari perusahaan-perusahaan di Indonesia, khususnya usaha mikro 
kecil dan menengah (UMKM). Sebab survei Deloitte menunjukkan 36\% UMKM terutama pada pengusaha batik lokal di Indonesia tidak memiliki akses broadband, komputer, smartphone dan situs jejaring.

Sementara itu, instagram juga digunakan oleh UMKM, khususnya jasa tour dan travel, untuk mempromosikan usahanya. Pengguna instagram di Indonesia merupakan terbesar di Asia Pasifik dengan lebih dari 45 juta pengguna aktif. Salah satu akun penyedia jasa tour dan travel di instagram yang kami wawancara membuka lebih dari 20 jenis perjalanan tiap bulannya untuk sekitar 40 tujuan wisata dari Labuan Bajo hingga Pegunungan Everest. Namun menurut Travel and Tourism Competitiveness Index, digitalisasi ini masih mengalami hambatan di sisi infrastruktur yang belum mendukung akses Internet cepat. Indonesia berada di peringkat ke-42 dari 136 negara pada 2017. Salah satu faktor yang menghambat adalah kesiapan sektor informasi, komunikasi, dan teknologi (Susilawati \& Wuryanta, 2020). Hal ini harus diperbaiki karena $82 \%$ turis menggunakan platform digital untuk mencari informasi tujuan wisata dan $73 \%$ berkomunikasi menggunakan media sosial ketika berwisata.

Secara khusus penelitian ini menunjukkan dalam komunikasi pemasaran, penyampaian informasi menjadi aktifitas paling penting. Informasi dalam komunikasi disebut juga sebagai pesan (message), dalam menyampaikan pesan, pemasar harus memperhatikan beberapa hal sebagai berikut:

Pertama, yang perlu digarisbawahi adalah pola pesan. Menurut Machfoedz (2010), bagian terpenting dari strategi penyampaian pesan pemasaran adalah penetapan cara terbaik untuk mengkomunikasikan pokok pesan kepada khalayak sasaran dalam hal ini adalah konsumen atau pelanggan. Ada dua faktor yang perlu diperhatikan dalam penyampaian pesan (presentasi), yaitu: isi pesan harus berorientasi pada produk dan tingkat kepedulian konsumen harus terbangun.

$\mathrm{Hal}$ ini dapat dilakukan dengan cara sebagai berikut: menyampaikan informasi yang sebenarnya tentang produk batik yang dijual, nenyisipkan humor-humor segar dalam status update, memberikan gambar-gambar produk batik yang inovatif dan menarik konsumen, dan menjawab pertanyaanpertanyaan konsumen tentang produk batik secara detail. Meyakinkan konsumen, batik lokal dapat dipercaya dengan memberikan nomor kontak dan email maupun intagram untuk kemudahan komunikasi.

Selanjutnya adalah pengaturan penyampaian pesan. Pengaturan frekuensi penyampaian pesan melalui media yang disediakan oleh intagram memang harus secara berkala dan terencana, adapun caracaranya adalah sebagai berikut: menyampaikan judul atau subyek pesan yang menarik, mengirim pesan secara personal kepada customer, bukan massal agar tidak dianggap sebagai spam, membuat pesan sesingkat dan sejelas mungkin, selalu akhiri dengan kontak, membuat jadwal dan frekuensi pengiriman pesan secara berkala.

Permasalahan penting lainnya adalah perancangan promosi. Promosi dilakukan untuk berkomunikasi dan mempengaruhi pelanggan agar dapat menerima produk yang dihasilkan. Pemasar dapat merancang promosi dengan berbagai cara, seperti periklanan, promosi penjualan, publisitas penjualan individu dan kemasan yang menarik. Batik lokal melakukan promosi melalui beberapa cara diantaranya: periklanan yang berarti bahwa menyampaikan pesan kepada konsumen berupa informasi produk, dalam bentuk gambar maupun deskripsi produk. Selanjutnya, promosi penjualan. Promosi penjualan dilakukan dengan cara membuat agenda promo khusus dalam masa tertentu secara berkala, misalnya menjelang lebaran membuat agenda pemasaran dengan memberikan diskon $20 \%$ untuk produk-produk tertentu dan dalam jumlah pembelian tertentu, menerima pesanan sarimbit keluarga ditambah anak, memberi bonus secara langsung berupa batik atau kain untuk para re-seller online maupun offline, mengadakan berbagai acara lomba untuk menarik konsumen.

Bagian lain adalah publisitas penjualan individu. Publisitas penjualan individu atau personal selling adalah menjual secara langsung kepada masing-masing konsumen, ini dapat dilakukan dengan cara berkomunikasi langsung dengan konsumen, baik dengan cara mengirim pesan atau dengan melakukan obrolan.

Terakhir, kemasan yang menarik. Kemasan produk atau product packing memiliki daya tarik tersendiri bagi konsumen, semakin menarik kemasan maka konsumen akan semakin tertarik untuk mengetahui produk lebih lanjut, maka penggantian kemasan secara berkala juga dibutuhkan untuk melakukan promosi pemasaran.

Tambahan dalam penelitian ini juga menggarisbawahi soal membangun komunitas. Dengan mengintegrasikan media sosial ke dalam sistem pemasaran, banyak hal yang dapat dilakukan guna meningkatkan efisiensi manajemen hubungan pelanggan (customer relationship management), hal- 
hal yang dilakukan Batik Burneh dengan intagram untuk adalah sebagai berikut: memanfaatkan group dan fans page melalui intagram. Group dan fans page atau halaman penggemar adalah sebuah layanan yang diberikan oleh intagram berupa halaman yang berisi informasi umum perusahaan/instansi yang dapat disukai (like) oleh pengguna intagram secara umum, sehingga pengguna yang menyukai halaman tersebut terkumpul menjadi satu komunitas penggemar. Interaksi yang terjadi adalah ketika pemilik halaman mengirimkan informasi ke halaman tersebut dan/atau salah satu penggemar mengirimkan informasi/komentar di halaman tersebut, maka seluruh penggemar yang tergabung akan menerima informasi yang dikirimkan tersebut, sehingga hal ini dipandang sangat efektif untuk pemasaran. Dalam hal ini batik lokal sudah membuat halaman fan page.

Optimalisasi intagram marketing melalui aplikasi intagram memiliki banyak fitur aplikasi yang dapat dimanfaatkan diantaranya adalah untuk mengadakan sebuah polling (jajak pendapat). Dengan aplikasi jajak pendapat ini, pemilik usaha/instansi akan mendapatkan umpan balik (feedback) dari pelanggannya secara acak, sehingga hasil dari jajak pendapat tersebut dapat digunakan untuk menentukan kebijakan selanjutnya.

\section{KESIMPULAN}

Hasil uji korelasi antara dua pendekatan menyatakan keduanya memiliki hubungan yang kuat. Artinya, jika akun instagram dimanfaatkan sebaik mungkin, maka akan berpengaruh besar pada peningkatan sikap khalayak. Merujuk pendapat dari Soemirat dan Ardianto (2010:115) mengenai komponen sikap khalayak, maka penelitian ini menguji seberapa besar pengaruh akun intagram promosi batik lokal melalui intagram mampu mempengaruhi persepsi, kognisi, motivasi, serta sikap followers.

Berdasarkan hasil penelitian di atas menunjukkan bahwa akun instagram Promosi Batik Lokal memiliki hasil yang positif dalam meningkatkan sikap khalayak batik lokal walau dengan menunjukkan nilai kontribusi tidak terlalu besar. Oleh karena itu, dapat disimpulkan akun instagram Promosi Batik Lokal belum terlalu efektif untuk meningkatkan sikap khalayak batik lokal daerah. Melihat dari responden yang sebagian besar berdomisili di daerah penelitian dan beberapa akun instagram yang sejenis lainnya, maka responden menyatakan hanya menggunakan akun instagram Promosi Batik Lokal sebagai media informasi batik lokal dan media hiburan saja.

Penelitian ini juga menemukan fakta, promosi dan pembentukan komunikasi pemasaran tetapi dengan media berbeda seperti Youtube yang mampu memberikan motivasi kepada anak muda atau khalayak lainnya, selain bahwa mereka juga harus membangun komunitas yang diperlukan untuk tetap membangun kesadaran dan pemahaman berikut promosi yang tepat untuk batik lokal. Untuk menciptakan suatu karya yang positif pada media YouTube dan mampu mengemas promosi tersebut dengan baik sehingga isi pesan dapat diterima baik juga oleh komunikan.

\section{DAFTAR PUSTAKA}

Agista, T. P. C., \& Handajani, S. (2019). The Power of Digital Media: Intagram and the Distribution of Kebaya Designs. KE Social Sciences, 395-404.

Appel, G., Grewal, L., Hadi, R., \& Stephen, A. T. (2020). The future of social media in marketing. Journal of the Academy of Marketing Science. https://doi.org/10.1007/s11747-019-00695-1

Al Mana, A. M., \& Mirza, A. A. (2013). The impact of electronic word of mouth on consumers' purchasing decisions. International Journal of Computer Applications, 82(9).

Basiroen, V. J., \& Oetojo, J. O. (2018). Digital Campaign as a Solution to Engage the Millennial's Awareness about Javanese Batik Pesisir. In 1st International Conference 2018: 276.

Balakrishnan, B. K. P. D., Dahnil, M. I., \& Yi, W. J. (2014). The Impact of Social Media Marketing Medium toward Purchase Intention and Brand Loyalty among Generation Y. Procedia - Social and Behavioral Sciences. https://doi.org/10.1016/j.sbspro.2014.07.032

Berg, L., \& Sterner, L. (2015). Marketing on Intagram: A qualitative study on how companies make use of Intagram as a marketing tool.

Berthon, P. R., Pitt, L. F., Plangger, K., \& Shapiro, D. (2012). Marketing meets Web 2.0, social media, and creative consumers: Implications for international marketing strategy. Business Horizons. https://doi.org/10.1016/j.bushor.2012.01.007

Felix, R., Rauschnabel, P. A., \& Hinsch, C. (2017). Elements of strategic social media marketing: A holistic framework. Journal of Business Research. https://doi.org/10.1016/j.jbusres.2016.05.001

Firmansyah, M. A., \& Se, M. (2019). Perilaku Konsumen (Sikap dan Pemasaran). Penerbit Qiara edia. 
Hafiar, H., Subekti, P., Komala, L., Komariah, K., \& Sani, A. (2019, March). Optimize your facebook features to improve your product's future: An opportunity to promote Batik Cimahi, West Java, Indonesia. Journal of Physics: Conference Series, 1175(1), 012220).

IconoSquare. (2018). Intagram Marketing. Trends \& Benchmarks Report.

Jin, S. V., Muqaddam, A., \& Ryu, E. (2019). Instafamous and social media influencer marketing. Marketing Intelligence and Planning. https://doi.org/10.1108/MIP-09-2018-0375

Kotler, Philip dan Kevin Lane Keller, 2016. Marketing Management. Edisi 15, Global Edition United Kingdom: Pcarson Education.

Marijke De Veirman, Veroline Cauberghe \& Liselot Hudders (2017) Marketing through Intagram influencers: the impact of number of followers and product divergence on brand attitude, International Journal of Advertising, 36(5), 798-828, DOI: 10.1080/02650487.2017.1348035

Moloy Ghoshal, D. (2019). Social Media as an Effective Tool to Promote Business- An Empirical Study. Global Journal Of Management And Business Research, Retrieved from https://journalofbusiness.org/index.php/GJMBR/article/view/2673

Morissan. (2015). Periklanan: Komunikasi Pemasaran Terpadu. Jakarta: Prenada Media Group.

Novendri, R., Callista, A. S., Pratama, D. N., \& Puspita, C. E. (2020). Sentiment Analysis of YouTube Movie Trailer Comments Using Naïve Bayes. Bulletin of Computer Science and Electrical Engineering, 1(1), 26-32. https://doi.org/10.25008/bcsee.v1i1.5

Robiatul, A., Suprina, R., \& Susanti, M. D. (2018, March). How does Griya Batik Mas Pekalongan Promote their Products? The Strategy and its Obstacle. 2nd International Conference on Tourism, Gastronomy, and Tourist Destination (ICTGTD 2018).

Singarimbun, M dan Effendi, 2008. Metode Penelitian Survey. Jakarta: LP3ES

Susilawati, N., \& Wuryanta, A. G. E. W. (2020). Tourism, Communications, and Disasters: Political Communication Management in Government Institutions on the Development Policy of Tourism Industry in Disaster-prone Areas Case Study: Planning on Special Economic Zones in the Mentawai Islands. https://doi.org/10.5220/0009401001230130

Sumarwan, U. (2011). Perilaku konsumen: Teori dan Penerapannya dalam Pemasaran. Bogor: Ghalia Indonesia.

Syafganti, I. (2018). Digital Transformation, Big Data and Research Landscape in Digital Communication. Jurnal Komunikasi Ikatan Sarjana Komunikasi Indonesia, 3(2), 99-106.

Tiago, M. T. P. M. B., \& Veríssimo, J. M. C. (2014). Digital marketing and social media: Why bother? Business Horizons. https://doi.org/10.1016/j.bushor.2014.07.002

Werdani, R. E., \& Djoko, W. H. (2018). The Effect of Social Media Usage to the Nonfinancial Performance and Financial Performance of Small Medium Enterprises (SMEs) Kampung Batik Semarang. Advanced Science Letters, 24(12), 9770-9773.

Widiastuti, T. (2019). The Implementation of Brand Element Strategic in Marketing Communication on Local Small-Medium Business in West Sumatra. Jurnal Komunikasi Ikatan Sarjana Komunikasi Indonesia, 4(1), 55-64.

Wiradinata, T., \& Iswandi, B. (2016). The analysis of Intagram Technology adoption as marketing tools by small medium enterprise. 3rd International Conference on Information Technology, Computer, and Electrical Engineering (ICITACEE) (1-6).

Wuryanta, A. G. E. W., \& Utami, A. T. (2020). Decorating our Kampong: Between Marketing Communication Strategy, Implementation Integrity and Development of Tourism Potential in Karangrejo Borobudur, Central Java. https://doi.org/10.5220/0009399900700075 